ISSN 2414-1143

Научный альманах стран Причерноморья. 2018. Том 15. № 3

DOI 10.23947/2414-1143-2018-15-3-61-64

UDC 001.89

\title{
THE INTERACTION OF THE STATE AND SCIENCE
}

\author{
(C) Yuri A. Zhdanov
}

\begin{abstract}
Yuri A. Zhdanov - Doctor of chemistry, candidate of philosophical sciences, professor. Rector of the Rostov state university (1957-1988 г2.).

Жданов Юрий Андреевич - доктор химических наук, кандидат фрилософрских наук, профрессор. Ректор Ростовского государственного университета (1957-1988 гг.).
\end{abstract}

Since the beginning of the 18th century the state has become the decisive force in the organization of science in Russia. Neither the peasants, nor the merchants and the church were active in this sphere. The noble and land-lordly class stimulated interests only in the sphere of history, philology and literature studying. At the same time, the state needs dictated the necessity of studying of geography, primary resourses of the country and engineering problems. The reforms of Peter the First laid the foundation of the academic and university science in Russia.

In the 19th century, the science development in Russia became a mission of the democratic intellectuals. Lobachevsky, Sechenov, Przhevalsky, Pavlov, Mendeleyev, Butlerov, Dokuchayev, Vernadsky, Vavilov came out of their ranks. The noble and land-lordly state lost interest in science and practically did not promote the development of its base. In Russia there was no scientific instrument making, chemical reagents production, the developing of information opportunities was very limited, there were almost no scientific magazines and publishing houses.

The Revolution of 1917 changed the situation resolutely. Thousands of research institutions, laboratories and higher educational institutions appeared, information technology and publishing were organized. The number of scientists increased from 10 thousand up to several million. The new centers in Kiev, Tbilisi, Yerevan, Baku, Rostov, Voronezh and many other cities were created. The modern base of scientific instrument making and reagents production were created. On this basis, it became possible to make a breakthrough in Space, the most important step in development of humanity after the fire mastering.

At the same time, the situation developed inconsistently, unevenly: there were sites of lag (biochemistry, computer science), conservative forces (genetics, sociology, psychology) worked.

It is necessary to emphasize that in the scientific and technical innovations the revolutionary ruling class relied on the best traditions of the Russian science; studying and use of natural resources of Russia actually were based on the program of Mendeleyev. Achievements in the field of mineralogy, geochemistry, radium business are the results of undertakings of V.I. Vernadsky. The shipbuilding development is included in works of the academician Krylov, the aircraft development is included in works of Zhukovsky, the astronautics development is included in works of Tsiolkovsky, the development of agriculture systems based upon the researches of Dokuchayev, Pryanishnikov, Gedroits. The construction of hydroelectric power stations on the plain rivers was proved in the researches of Krzhizhanovsky, 
Vinter, Graftio. The traditions of Struve led to the creation of the largest astronomical center of Europe in the Caucasus.

Nobel Prize laureates (Sechenev, Kapitsa, Prokhorov, Basov, etc.) appeared in the Russian science.

Contradictory society development first of all was connected with bureaucratization of the party and state elite which had lost its initial revolutionary impulse and had been gradually transformed into the conservative and parasitic class. During the so-called thaw the considerable part of the government and party apparatus became a philistine, it lost its interest in national objectives, citizens living conditions in favor of its profit. As the great Russian democrat Herzen noted, all the history rivers are lost in swamps of philistinism. Both the English historian Toynbee, and L. Gumilyov had the same point of view. The refusal of a number of outdated ideological dogmas led to the typical for Russia shrinking from something. Thus a part of bureaucracy and intellectuals shrank from rationalism, scientific understanding of the world. On this basis the confidence to the scientific planning, to the science and education in general was undermined, the obscurantism moods, thirst for occultism, archaic outlooks, chiromancy, astrology, magic and so forth had revived.

It should be noted that the similar processes connected with reaction against rationalism, scientific perception, reality are widespread in the modern West. There is no doubt that all this is caused by the general crisis of culture which began in the middle of the last century.

The self-interested, ignorant policy of parasitic elite and pseudo-educated people led to the crash of the Soviet Union, to the deepest political, economic, social and cultural crisis. This crisis also touched upon science in Russia. The facts are well-known. Crisis recovery is possible only on the basis of revival of statehood in Russia and recovery of the state scientific policy. This process has already become a historical tradition.

At the same time Vernadsky's thought that the state has to give means, bring the scientific organizations into the world, create tasks for them, must be embodied. But we have to remember and know that the state cannot interfere in scientific creative work more than that. Science, like religion, philosophy or art, represents the spiritual field of human creativity, on its basis deeper and more powerful, more eternal, than any social forms of human life. It prevails in itself. It is free and there is not any framework for it.

The most important national goal of science in Russia is the rational organization of social production on the basis of scientific foresight of the processes happening in technology, economy and ecology.

People calling nowadays to catch up with the western civilization do not wish or are not able to see that the basis of modern industrial society is the developed technostructure. Science and education were cornerstones of this technostructure and nowadays they remain its cornerstones. Technical progress and more wide and far-sighted program of forecasting and planning of social development, foresight of social and ecological processes and transition to the information society are carried out only on the basis of science and education.

As for the new market elite arising in Russia, it is recruited considerably at the expense of parasitic classes of former elite and rich people therefore it will not show real interest in science, especially fundamental one. Its politicians' and ideologists' thoughts about the necessity to enter the world civilization, about universal values have got demagogical and advertizing character. The science cannot be developed on tips.

"The demonic force of ignorance" built a nest (Marx) in the market and mafia sphere, here separate self-advertizing fireworks in the form of support of single projects and creation of some funds are possible. But it will not influence the general condition of science. 
Being in captivity of psychology of small shopkeepers, they do not understand that cost estimates (how much does relativity theory cost?) are not applicable to the science, they can work only in the sphere of science application to the production.

By the nature the science is universal and international, the possibility of international cooperation of scientists consist in this fact. Such cooperation has to develop both within the $\mathrm{CIS}$, and on the global scale. Formation of the international programs is the most important condition of science revival in Russia.

Historical experience demonstrates that development of truly democratic, but not ochlocratic principles in modern society is possible only on the basis of the union of science and democracy. In this regard democratization of science, formation of free associations of scientists, non-state structures of science and education are important.

The tendency to continuous education of the population, with wide use of telecommunication means has to play an essential role. Democracy cannot rely on ignorance and on the ignorant power.

Science in the North Caucasus is an offspring of the Soviet power, before revolution its level was minimal, 880 scientific experts are listed in the collection "Scientists and Scientific Institutions of the North Caucasus" published in Rostov in 1927. At present, there are 42 thousand of scientists, including 13 thousand candidates and 1300 doctors of science. Research teams on the most important areas of basic and applied researches are created in the region. In a number of the directions, the level of scientific works in the region reached a world class (mechanics, chemistry, physics, astrophysics, neurocybernetics, and cultural science).

The science in the North Caucasus developed in earlier backward national republics quickly and it is extremely important. This process of internationalization of science is a part of democratic development and has to be supported by the state. Nowadays this process promoted by the forming scientific centers in the republics and again arising branch academies of Sciences. The North Caucasian scientific center of the higher school also contributes to these processes. The natural aspiration to integrate activity of these structures led to the organization of the Academic association of the North Caucasus on a voluntary basis. Special attention has to be paid on youth, on the attraction of youth both to the scientific creativity, and to the scientific thinking. The state is called for to develop children's technical stations, network of stations of young naturalists, ecologists, astronomers, historians, philologists. Here there is an immense field of activity for mass media.

Measures for development of mass scientific and cognitive activity among all social groups, first of all, among youth have to be taken. Despite all the technical and mental difficulties of modern science the involvement of mass of amateur researchers into the study of issues of environmental, geography, geology, hydrology, climatology, zoology and botany, selection and genetics, observation astronomy is possible. The young researcher with the help of skilled consultant can contribute to the research of humanitarian problems: demography and economy, history and archeology, linguistics and folklore studies. The extensive field has to be opened for technical creativity of youth, the designing and the modeling. In this way the democratic base of science has to expand and the intellectual potential of the nation has to increase. Thus, people's leisure time, their free time will not be exhausted by passive and spectacular and entertaining forms, and will become a basis of their self-development and communication. It will demand the creation of the mass industry of knowledge and experimenting, observation and designing where the market relations so alien to pure science can realize themselves. 
Production of telescopes, microscopes, the special photoequipment, phytothrones, aquariums, measuring devices and materials for design engineering has to take the mass forms. And it is necessary to advertize not only chocolate, but also telescopes which are the knowledge sources. It's high time to combine public efforts and focus them on theoretical and practical study of problems of anthroposphere as the space phenomenon as the key problem of the 21st century. The problem does not come down to ecology.

The long historical process brought mankind to this boundary. According to Hegel, history, unfortunately, has not taught anybody anything, and only the threat of self-destruction can force everybody to think. The moment has come. Vernadsky, Lenin and Einstein were almost the first who noticed this moment.

At the same time the mind has to act not only educationally (it was in the 18th century) not as rationalistic abstraction (Kant, Hegel), not in the behaviorist and cortical way, but in deeper aspect. As Vernadsky emphasized scientific thought is a planetary phenomenon, therefore anthroposphere is a new condition of biosphere, not only mental but also geological and, moreover, space phenomenon. From the point of view of sociology, anthroposphere is a new basis of all historical process. Transition to the anthroposphere is a change of the basis of human history and history of the planet. This basis must be created both as public and as personal, it must be an interest and passion of a separate individual, it must be connected with emotional tension, esthetic sense of beauty and activity. All these processes present difficulties. The productively acting and creative person can be developed only in this way. The solution of this problem demands the profound analysis of global spheres: biospheres, anthropospheres, technospheres. It is necessary to reflect on Mendeleyev's idea that the technology does not come down to the supplement of fundamental sciences to practical tasks. According to the scientist, the technology is a fundamental science. Its object is evolution of technosphere.

It is necessary to overcome empirical idea of culture and to base cultural development on the internal logic of culture. At the same time, Charles Percy "C. P." Snow's dilemma of overcoming development of two cultures, scientific and humanitarian, has to be solved.

Government institutions of society have to understand the importance of these issues and promote their solving.

Опубликовано на русском языке в издании: Государственность, право, местное самоуправление (материалы научно-практической конфреренции). Ростов-на-Дону, 1993. С 11-17.

На английском языке публикуется впервые.

The article is published in Russian in the edition: Statehood, right, local self-government (proceedings of a scientific-practical conference). Rostov-on-Don, 1993. p. 11-17.

In English it is published for the first time.

August 30, 2018 